\title{
Caryospora bigenetica (Apicomplexa: Eimeriidae) in South America: new hosts and distribution records
}

\author{
Caryospora bigenetica (Apicomplexa: Eimeriidae) na América do Sul: \\ Registro de novos hospedeiros e distribuição
}

Lúcio André Viana ${ }^{1 *}$; Kamilla Costa Mecchi²; Leonardo França do Nascimento²; Heitor Miraglia Herrera²; Paula Helena Santa-Rita²; Marcos Tobias de Santana Miglionico ${ }^{3}$; Rhaiza Gama Esteves ${ }^{4}$; Anibal Rafael Melgarejo Gimenez ${ }^{4}$; Fernando Paiva ${ }^{1}$

\footnotetext{
${ }^{1}$ Laboratório de Parasitologia Veterinária, Centro de Ciências Biológicas e da Saúde, Universidade Federal do Mato Grosso do Sul - UFMS, Campo Grande, MS, Brasil

${ }^{2}$ Universidade Católica Dom Bosco - UCDB, Campo Grande, MS, Brasil

${ }^{3}$ Hospital Universitário Pedro Ernesto, Instituto de Biologia Roberto Alcântara Gomes, Universidade do Estado do Rio de Janeiro - UERJ, Rio de Janeiro, RJ, Brasil

${ }^{4}$ Divisão de Zoologia Médica, Instituto Vital Brazil - IVB, Niterói, Rio de Janeiro, Brasil
}

Received September 03, 2014

Accepted November 03, 2014

\begin{abstract}
The coccidian Caryospora bigenetica was first described in the snake Crotalus horridus (Viperidae) from United States of America. This study represents the first record of the occurrence of $C$. bigenetica in snakes in South America. Feces were sampled between November 2013 and May 2014 from 256 wild snakes maintained in scientific breeding facilities in the states of Mato Grosso do Sul (MS; $\mathrm{n}=214$ ) and Rio de Janeiro (RJ; $\mathrm{n}=42$ ), Brazil. Caryospora bigenetica was found in 14 (5.6\%) snakes, all belonging to the family Viperidae. Ten Bothrops moojeni and two Crotalus durissus from MS were infected. The coccidian was also found in one C. durissus and in one Bothrops jararacussu from the state of RJ. The oocysts were spherical with a double wall, the exterior lightly mammillated, striations apparent in transverse view, $13.0 \mu \mathrm{m}(12-14)$; polar granule fixed in the internal wall. Sporocysts oval or pyriform, $10.0 \times 8.0 \mu \mathrm{m}(9-11 \times 8-9)$; Stieda body discoid; sub-Stieda body present; sporocyst residuum present, formed by a group of spheroid bodies between sporozoites. This study increases the number of viperid hosts of $C$. bigenetica and expands the geographical distribution to South America.
\end{abstract}

Keywords: Snakes, Coccidia, Bothrops, Crotalus, Caryospora bigenetica, Viperidae.

\section{Resumo}

O coccídio Caryospora bigenetica foi descrito na serpente Crotalus horridus (Viperidae) nos Estados Unidos da América. Este estudo representa o primeiro registro da ocorrência de C. bigenetica em serpentes da América do Sul. Amostras de fezes foram obtidas, entre novembro de 2013 e maio de 2014, de 256 serpentes silvestres mantidas em um criatório científico nos Estados do Mato Grosso do Sul (MS; n = 214) e Rio de Janeiro (RJ; n = 42), Brasil. Caryospora bigenetica foi encontrada em 14 (5,6\%) serpentes, todas pertencentes à família Viperidae. Dez Bothrops moojeni e duas Crotalus durissus de MS estavam infectadas. O coccídio também foi encontrado em uma C. durissus e uma Bothrops jararacussu do Estado do Rio de Janeiro. Os oocistos foram esféricos, com parede dupla, sendo a externa ligeiramente mamilonada, estriaçôes aparentes transversalmente, $13.0 \mu \mathrm{m}(12$ - 14); grânulo polar junto à parede interna. Esporocisto oval ou piriforme, $10.0 \times 8.0 \mu \mathrm{m}(9-11 \times 8-9)$; corpo de Stieda discóide; sub-Stieda presente; resíduo do esporocisto presente, formado por um grupo de corpos esféricos entre os esporozoítos. Este estudo aumenta o número de hospedeiros viperídeos de C. bigenetica e expande a distribuição geográfica para a América do Sul.

Palavras-chave: Serpentes, Coccidia, Bothrops, Crotalus, Caryospora bigenetica, Viperidae.

\footnotetext{
*Corresponding author: Lúcio André Viana, Laboratório de Parasitologia Veterinária, Centro de Ciências Biológicas e da Saúde, Universidade Federal do Mato Grosso do Sul, Cidade Universitária, CP 549, CEP 79070-900, Campo Grande, MS, Brazil, e-mail: lucviana74@gmail.com
} 


\section{Introduction}

The parasitic protozoans of the genus Caryospora belong to the Phylum Apicomplexa. The members of this genus colonize the digestive tracts of reptiles and birds. The genus is characterized by oocysts with a single, octozoic sporocyst, and the species with known life cycles are facultatively or obligatorily heteroxenous with merogony and gamogony in both primary (predator) and secondary (prey) hosts (UPTON et al., 1986).

The coccidian Caryospora bigenetica was first described in the snake Crotalus horridus in Iowa, USA, by Wacha \& Christiansen (1982). Subsequently, it has been reported infecting Sistrurus catenatus, Sistrurus miliaris, Agkistrodon contortrix, Crotalus adamanteus and Crotalus atrox, all species belonging to the subfamily Crotalinae of the family Viperidae (DUSZYNSKI \& UPTON, 2009). Moreover, experimental infections have been investigated in many species of mammals, including Canis familiaris, Sus scrofa, Mus musculus and Capra hircus. Previously, the geographical distribution of $C$. bigenetica included only the states of Arkansas, Georgia, Iowa, New Jersey and Texas, USA (DUSZYNSKI \& UPTON, 2009).

The only coccidian species previously described in Brazilian snakes of the family Viperidae is Caryospora jararacae, found in Bothrops jararaca and Bothrops atrox (CARINI, 1939; LAINSON et al., 1991). However, 36 species of the family Viperidae are found in Brazil. These species belong to the genera Bothrops $(\mathrm{n}=27)$, Crotalus $(\mathrm{n}=6)$, Bothrocophias $(\mathrm{n}=2)$ and Lachesis ( $\mathrm{n}=1$ ) (BÉRNILS \& COSTA, 2012). As part of a study of coccidian diversity in Brazilian snakes, this study represents the first report of a natural C. bigenetica infection in South American viperid snakes.

\section{Materials and Methods}

Snake feces were sampled between November 2013 and May 2014. Snakes were obtained from various localities in the state of Mato Grosso do Sul (MS), Brazil, via donations from local residents and environmental agencies such as the Center for Rehabilitation of Wild Animals (CRAS), Environmental Military Police and Fire Brigade. The animals were transported to the bioterium of Dom Bosco Catholic University (UCDB) in the county of Campo Grande. Snakes sampled at the Vital Brazil Institute in the state of Rio de Janeiro (RJ) were from various parts of the state and were obtained, as in the case of the UCDB specimens, via donations from local residents and environmental agencies. Two snakes were obtained from states other than MS and RJ. A B. atrox specimen was obtained from the county of Porto Velho, state of Rondonia, and Bothrops insularis specimen was obtained from the Island of Queimada Grande, between Itanhaém and Peruíbe counties in the state of São Paulo. Specimens were kept separated in polyethylene boxes $(39 \mathrm{~cm}$ x $59 \mathrm{~cm} \times 31 \mathrm{~cm}$ ) with covers and with holes in the sides. All boxes had a corrugated substrate. In each box, water was provided in an aluminum container with an iron base. Live mice (M. musculus) were supplied as food. The UCDB biotherium is accredited by the Brazilian Institute of Environment and Renewable Natural Resources (IBAMA), registration number 170855.

The feces were placed in plastic vials containing a $2.5 \%(\mathrm{w} / \mathrm{v})$ (i.e., a 1:6 v/v ratio) $\mathrm{K}_{2} \mathrm{Cr}_{2} \mathrm{O}_{7}$ solution and processed at the Laboratory of Veterinary Parasitology, Universidade Federal do Mato Grosso do Sul (UFMS). The fecal material was placed on a thin layer $(-5 \mathrm{~mm})$ of $2.5 \%(\mathrm{w} / \mathrm{v}) \mathrm{K}_{2} \mathrm{Cr}_{2} \mathrm{O}_{7}$ solution in Petri dishes and incubated at $23-28^{\circ} \mathrm{C}$ for two weeks. Oocysts were recovered by flotation in Sheather's sugar solution (S.G. 1.20) and microscopically examined (DUSZYNSKI \& WILBER, 1997). Morphological observations and measurements $(\mu \mathrm{m})$ were performed using a Carl Zeiss binocular microscope with an apochromatic oil immersion objective lens and ocular micrometer. Oocysts were photographed with a Zeiss universal photomicroscope equipped with Nomarski interference $100 \times$ objective lenses. The size ranges are shown in parentheses, followed by the average and shape index (L/W ratio). All measurements are given in micrometres $(\mu \mathrm{m})$. At least five measurements of each infected snake were recorded.

Photomicrographs of sporulated oocysts are deposited and available in the Parasitology Collection of the Laboratório de Coccídios e Coccidioses (http://r1.ufrrj.br/lcc), at UFRRJ, located in Seropédica, Rio de Janeiro, Brazil. Photographs of the host specimens are deposited in the same collection. The repository number is $\mathrm{P}-57 / 2014$.

\section{Results}

We performed coprological examinations of 214 snakes from MS belonging to 10 species (Table 1) and 42 snakes belonging to 8 species maintained in the Vital Brazil Institute, RJ (Table 2). Oocysts of $C$. bigenetica were found in 6\% (12/214) of the specimens from MS, i.e., 10 Bothrops moojeni and two Crotalus durissus, and in 5\% (2/40) of the specimens from RJ, i.e., one C. durissus and one Bothrops jararacussu.

The oocysts were spheroidal with a double wall, $\approx 1.0$, the exterior lightly mammillated, striations apparent in transverse view (Figures 1 and 2), $\mathrm{L} \times \mathrm{W}(\mathrm{N}=70): 13.0(12-14)$; $/ \mathrm{W}$ ratio 1.0; micropyle and oocyst residuum absent and polar granule fixed in the internal wall. Ovoid or pyriform sporocysts, $\mathrm{L} \times \mathrm{W}$

Table 1. Snakes examined for presence of coccidians from state of Mato Grosso do Sul.

\begin{tabular}{lccc}
\hline \multicolumn{1}{c}{ Species } & Total & Positive & $\%$ \\
\hline Bothrops moojeni & 83 & 10 & 12 \\
Crotalus durissus & 59 & 2 & 3 \\
Bothrops alternatus & 34 & 0 & 0 \\
Bothrops matogrossenssis & 19 & 0 & 0 \\
Sibynomorphus mikanii & 6 & 0 & 0 \\
Oxyrhopus trigeminus & 5 & 0 & 0 \\
Boa constrictor & 4 & 0 & 0 \\
Erythrolamprus poecilogyrus & 2 & 0 & 0 \\
Philodryas olfersii & 1 & 0 & 0 \\
Xenodon merremii & 1 & 0 & 0 \\
Total general & 214 & 12 & 5.6 \\
\hline
\end{tabular}



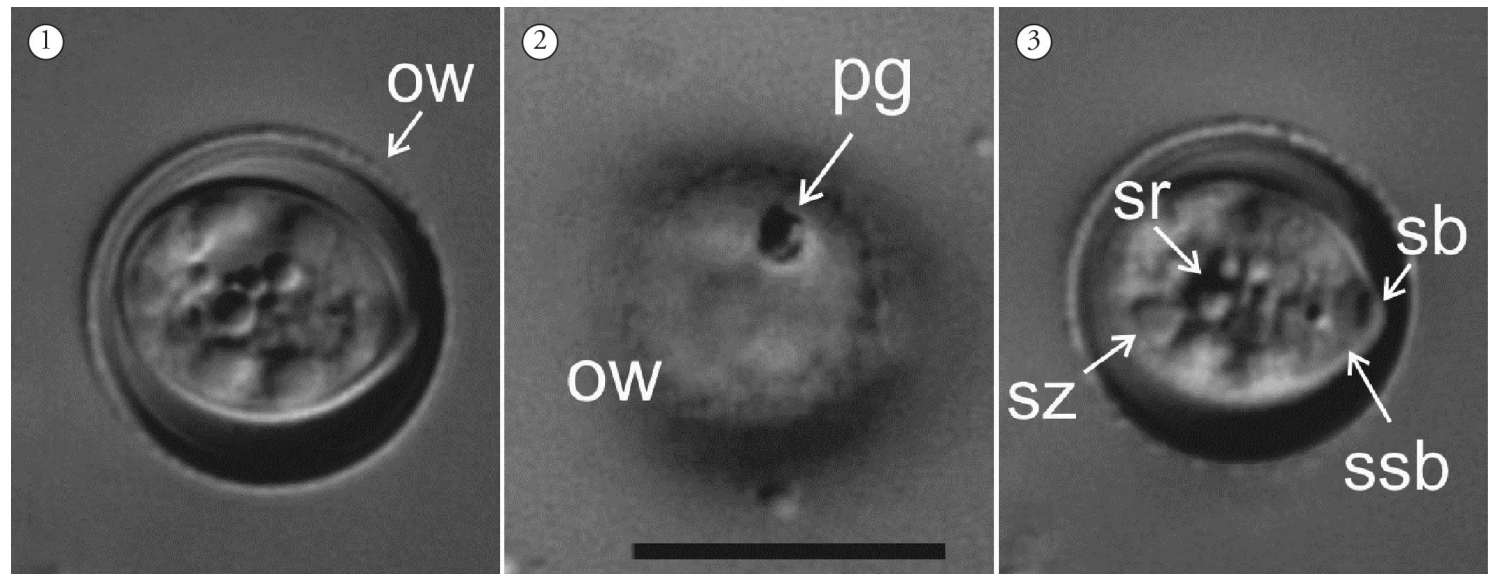

Figures 1-3. Nomarski interference-contrast photomicrographs of the sporulated oocyst of Caryospora bigenetica from Crotalus durissus. Figure 1. Oocyst showing striations (ow) in transverse view. Figure 2. Textured outer wall of oocyst (ow) and polar granule (pg). Figure 3. Sporocyst showing residuum (sr), Stieda body (sb) discoid and sub-Stieda body (ssb), and sporozoite extremity (sz). Bar $=10 \mu \mathrm{m}$ for all figures.

Table 2. Snakes examined for presence of coccidians from Instituto Vital Brazil, state of Rio de Janeiro.

\begin{tabular}{lccc}
\hline \multicolumn{1}{c}{ Species } & Total & Positive & $\%$ \\
\hline Bothrops jararacussu & 23 & 1 & 4 \\
Bothrops atrox & 9 & 0 & 0 \\
Bothrops jararaca & 3 & 0 & 0 \\
Bothrops insularis & 2 & 0 & 0 \\
Bothrops neuwiedi & 2 & 0 & 0 \\
Boa constrictor & 1 & 0 & 0 \\
Bothrops moojeni & 1 & 0 & 0 \\
Crotalus durissus & 1 & 1 & 100 \\
Total general & 42 & 2 & 5 \\
\hline
\end{tabular}

$(\mathrm{N}=70): 10.0 \times 8.0(9-11 \times 8-9) ; \mathrm{L} / \mathrm{W}$ ratio 1.3 ; Stieda body discoid; sub-Stieda body present; paraStieda body absent; sporocyst residuum present, formed by a group of spheroid bodies between sporozoites (Figure 3).

\section{Discussion}

Although 381 species of snakes occur in Brazil (BÉRNILS \& COSTA, 2012), there is only 12 records for coccidians (3\%) (DUSZYNSKI \& UPTON, 2009). This diversity is probably due to low amount of snake sampling and not the mere absence of coccidian infection. The last two records of new species of coccidians of snakes in Brazil have an interval of 22 years between them. They recorded six new species of Caryospora in the northern region of the country (Lainson et al., 1991) and Caryospora olfersii in Philodryas olfersii in the southeastern region (VIANA et al., 2013).

In this study the oocysts found in $C$. durissus, B. moojeni and Bothrops jararacussu were morphologically and morphometrically identical to the original description of $C$. bigenetica in $C$. horridus (WACHA \& CHRISTIANSEN, 1982). It is noteworthy, that in a previous study with snakes from Vital Brazil Institute was recorded prevalence of $75 \%$ of Caryospora sp. in C. durissus, B. mooojeni, and B. jararacussu (SOUZA et al., 2014).
Among snakes examinated in this study only three have formal descriptions for Caryospora species. Carini (1939) described Caryospora jararacae in $B$. jararaca and later also recorded in B. atrox (LAINSON et al., 1991), both of Viperidae. In P. olfersii (Colubridae) there are records of two caryosporans species, C. brasiliensis Carini, 1932 and C. olfersii Viana et al., 2013. These last species can be differentiated from $C$. bigenetica by size of oocysts, $33.1 \times 31.2 \mu \mathrm{m}$ for $C$. olfersii and $21.7 \times 20.8 \mu \mathrm{m}$ for C. brasiliensis, and both the polar granule is absent. Caryospora jararacae is distinguished by oocyst formed by one entirely smooth wall, unlike of $C$. bigenetica with dual wall lightly mammillated, and striations apparent in transverse view. Another closely related species is $C$. simplex, but this presents oocysts with one single wall. Additionally, C. simplex has only been recorded in the subfamily Viperinae, specifically in genus Daboai and Vipera, and restricted geographic distribution to Europe. While C. bigenetica appears restricted to the species of subfamily Crotalinae and the American continent (DUSZYNSKI \& UPTON, 2009).

The prevalence of $C$. bigenetica in MS was four times greater in B. moojeni than in C. durissus. Note that the snakes originated from several locations in MS and that different numbers of animals were sampled for each species. However, it is probable that the observed difference was associated with the type of habitat used by both species of snakes. Bothrops moojeni inhabits shaded places, such as gallery forests and wetlands (NOGUEIRA et al., 2003). C. durissus is found in open, dry vegetation as that of the Brazilian Cerrado (COLLI et al., 2002), Caatinga and Chaco biomes (CAMPBELL \& LAMAR, 2004). Most likely, the viability/ availability of oocysts is less in dry and sunny environments such as those found in midwestern Brazil. Observations consistent with this suggestion have been recorded from natural populations of lizards (MCALLISTER et al., 1994) and rodents of the family Heteromyidae infected by coccidia (FORD et al., 1990). Experimental studies have shown that high levels of relative humidity and ambient temperature have a negative effect on the survival of coccidia (MARQUARDT et al., 1960; LANGKJAER \& ROEPSTORFF, 2008). 
Experimental infections with Caryospora spp. have shown that rodents are potential secondary hosts in natural cycles involving colubrids (MODRÝ et al., 2005) and viperid snakes (UPTON \& BARNARD, 1988, KOUDELA et al., 2000). However, other food items, such as frogs and lizards, may be associated with the transmission of $C$. bigenetica under natural conditions. In a study of ontogenetic variation in the diet of $B$. moojeni, young individuals consumed relatively more frogs and lizards (76\%) than mammals and birds (20\%) (NOGUEIRA et al., 2003). In contrast, adult females showed a reversal of this pattern. Interestingly, two $B$. moojeni found to be infected by the current study have been observed preying on amphibians at a lagoon (K. MECCHI, personal obs.). Experimental infection studies are needed to clarify the involvement of these vertebrates in transmission cycles.

This study increases the number of viperid hosts of $C$. bigenetica and expands the geographic distribution of this protozoan to South America. The diversity of viperids in Brazil suggests that other Brazilian snake species can be infected by C. bigenetica.

\section{References}

Bérnils RS, Costa HC. Brazilian reptiles: list of species. Version 2012.2 [online] 2012 [cited 2014 July 24]. Available from: www.sbherpetologia. org.br/

Campbell JA, Lamar WW. The venomous reptiles of the Western Hemisphere. Ithaca: Cornell University Press; 2004.

Carini A. Sobre uma cariospora da jararaca. Arq Biol São Paulo 1939; 23(213): 41-42.

Colli GR, Bastos RP, Araújo AFB. The character and dynamics of the Cerrado herpetofauna. In: Oliveira PS, Marquis RJ. The cerrados of Brazil: ecology and natural history of a neotropical Savanna. New York: Columbia University Press; 2002. p. 223-241.

Duszynski D, Upton J. The Biology of the Coccidia (Apicomplexa) of Snakes of the World. USA: Create Space; 2009.

Duszynski DW, Wilber PG. A guideline for the preparation of species descriptions in the Eimeriidae. J Parasitol 1997; 83(2): 333-336. http:// dx.doi.org/10.2307/3284470. PMid:9105325

Ford PL, Duszynski DW, McAllister CT. Coccidia (Apicomplexa) from heteromyid rodents in the southwestern United States, Baja California, and northern Mexico with three new species from Chaetodipus hispidus. J Parasitol 1990; 76(3): 325-331. http://dx.doi.org/10.2307/3282659. PMid:2352062
Koudela B, Modrý D, Volf J, Slapeta JR. SCID mice as a tool for evaluation of heteroxenous life cycle pattern of Caryospora (Apicomplexa, Eimeriidae) species. Vet Parasitol 2000; 92(3): 191-198. http://dx.doi. org/10.1016/S0304-4017(00)00316-2. PMid:10962156

Lainson R, Nascimento FP, Shaw JJ. Some new species of Caryospora (Apicomplexa, Eimeriidae) from Brazilian snakes, and a re-description of C. jararacae Carini, 1939. Mem Inst Oswaldo Cruz 1991; 86(3): 349-364. http://dx.doi.org/10.1590/S0074-02761991000300009.

Langkjaer M, Roepstorff A. Survival of Isospora suis oocysts under controlled environmental conditions. Vet Parasitol 2008; 152(3-4): 186193. http://dx.doi.org/10.1016/j.vetpar.2008.01.006. PMid:18289796

Marquardt WC, Senger CM, Seghetti LEE. The effect of physical and chemical agents on the oocyst of Eimeria zurnii (Protozoa, Coccidia). J Protozool 1960; 7(2): 186-189. http://dx.doi. org/10.1111/j.1550-7408.1960.tb00728.x.

McAllister CT, Upton SJ, Trauth SE. New host and distribution records for coccidia (Apicomplexa: Eimeriidae) from north american lizards (Reptilia: Sauria). J Helminthol Soc Wash 1994; 61(2): 221-224.

Modrý D, Slapeta JR, Koudela B. Mice serve as paratenic hosts for the transmission of Caryospora duszynskii (Apicomplexa: Eimeriidae) between snakes of the genus Elaphe. Folia Parasitol (Praha) 2005; 52(3): 205-208. http://dx.doi.org/10.14411/fp.2005.027. PMid:16270800

Nogueira C, Sawaya RJ, Martins M. Ecology of the Pitviper, Bothrops moojeni, in the Brazilian Cerrado. J Herpetol 2003; 37(4): 653-659. http://dx.doi.org/10.1670/120-02A.

Souza JL, Barbosa AS, Vazon AP, Uchôa CMA, Nunes BC, Cortez $\mathrm{MBV}$, et al. Parasitological and immunological diagnoses from feces of captive-bred snakes at Vital Brazil Institute. Rev Bras Parasitol Vet 2014; 23(2): 123-128. http://dx.doi.org/10.1590/S1984-29612014032. PMid:25054488

Upton SJ, Barnard SM. Development of Caryospora bigenetica (Apicomplexa: Eimeriorina) in experimentally infected mice. Int J Parasitol 1988; 18(1): 15-20. http://dx.doi.org/10.1016/00207519(88)90030-6. PMid:3366533

Upton SJ, Current WL, Barnard SM. A review of the genus Caryospora Léger, 1904 (Apicomplexa: Eimeriidae). Syst Parasitol 1986; 8(1): 3-21. http://dx.doi.org/10.1007/BF00010305.

Viana LA, Winck GR, Coelho CD, Flausino W, Duarte Rocha CF. A new species of Caryospora Léger, 1904 (Apicomplexa: Eimeriidae) from the snake Philodryas olfersii Lichtenstein (Colubridae) from a coastal habitat in Brazil. Syst Parasitol 2013; 85(2): 195-199. http://dx.doi.org/10.1007/ s11230-013-9420-0. PMid:23673697

Wacha RS, Christiansen JL. Development of Caryospora bigenetica n. sp. (Apicomplexa, Eimeriidae) in rattlesnakes and laboratory mice. J Protozool 1982; 29(2): 272-278. http://dx.doi.org/10.1111/j.1550-7408.1982. tb04026.x. 